\title{
Communication and Conflict of North Coast Resources Utilization in Serang Regency
}

Komunitas: International Journal of Indonesian Society and Culture 11(1) (2019):85-98

DOI:10.15294/komunitas.v11i1.18051 (C) 2019 Semarang State University, Indonesia p-ISSN 2086 - 5465 | e-ISSN 2460-7320 http://journal.unnes.ac.id/nju/index.php/komunitas

UNNDS JOURNALS

${ }^{1}$ Faculty of Social and Political Science, Universitas Sultan Ageng Tirtayasa

23,4 Faculty of Human Ecology, Institut Pertanian Bogor

Received: February 10, 2018; Accepted: March 1, 2019; Published: March 30, 2019

\begin{abstract}
The gap in the coastal resources utilization on the North Coast in Serang Regency has the potential to cause conflict between coastal communities dealing with local governments and sea sand mining companies. This research focuses on how the communication practices of the conflicting parties and the typology of conflict, communication interactions in conflict relations and communication strategies in conflict solutions. The research used qualitative approach which was conducted through in-depth interview with informants purposively. The results of the research showed that the dominance of natural resources was the trigger for conflict in the utilization of coastal resources on the North Coast in Serang Regency. The ineffectiveness of government and company communication in managing conflict potentials made coastal communities perceived the sea sand mining activities negatively. Coastal communities fought for their interests in various forms namely demonstrations, anarchism, social conflict between layers and human rights violations. The most active community groups were fishermen because sea sand mining had caused technical problems with fishing and decrease in income. The conflicting parties communicated with each other openly, defensively and in confrontational way. The practice of communication in resolving conflicts ran less effectively because the government and the company did not involve conflicting parties through communication to resolve the conflict. The research findings are the basis of understanding to manage potential conflicts and its escalations through appropriate communication to reach consensus to realize convergence of interests.
\end{abstract}

\section{Keywords}

communication strategy; natural resource conflict; conflict resolution

\section{INTRODUCTION}

Coastal resources utilization conflict is originally caused by access gap and no convergence of interests due to appropriate communication. Agricultural and natural resource conflicts (NRC) in Indonesia after the new order era were increasingly high and increasing from latent to manifest conflict accompanied by human rights violations (HuMa, 2013; KPA, 2015). Agricultural and natural resources conflicts had increased in the reform era as the change of system of state ownership to natural resources which were no longer centralistic but it has been decentralized by the government. Local governments have the authority to manage natural resources in their regions based on Constitution No. 32 of 2004 which

\footnotetext{
Corresponding author

Jl. Raya Jakarta Km 4 Pakupatan, Serang City, Banten Province

Email

ail.muldi@untirta.ac.id
} 
was revised into Constitution No. 23 of 2014 concerning on regional government. Local government has the potential to increase Regional Original Revenue (ROR) from natural resources based on Constitution No. 33 of 2004 concerning on financial balance between the central and regional governments.

Decentralization encouraged the Government of Serang Regency to exploit sea sand. Sea sand exploitation which is intended to increase ROR is a political driven of regional and government head. The sea sand exploitation activities were getting higher along with market demand. Local governments were more accommodating with capital penetration from outside the region which was often counter-productive with justice, welfare, and sustainability of natural resources (Nurzal, 2004). Sea sand exploitation was ecologically very detrimental and harmed small islands as well as coastal communities who worked as fishermen who utilized fisheries resources as a source of livelihood (Satria, 2009).

Government and company policies in the utilization of natural resources were dominated and the terms of interest of funders were from outsiders. The source of the conflict came from the market economy domination towards the control of natural resources. The structural natural resource conflicts have various, chronic, comprehensive problems and these were sensitive to issues of social justice. Natural resource conflicts occurred in various forms, such as demonstrations, anarchism, social conflicts between layers, separatist movements, and human rights violations (Sumardjo, 2015).

Latent (closed) interest groups become manifest (open) if there are brave leaders to have conflict relations, groups which have conflict ideologies, group members who are free to organize conflicts and have members who are committed and communicate with others (Dahrendorf 1986). Conflict is most likely to occur when quasi-group between coordinated groups are aware of their interests objectively and collectively so as to form conflict groups (Turner, 1998). Conflict becomes apparent depending on the communication process in building member identity and group collectivity in conflict groups (Kreisberg 2003). The conflict turns brutal because of the lack of communication channels (Engel \& Korf 2005). The closure of dialogue results in resentment, political resistance, violence and escalation (Susan, 2009).

Fishermen were getting bolder to fight for their interests in public in the era of decentralization (Kinseng, 2017). Fishermen in Balik Papan and East Kalimantan were fighting for their rights and lives by carrying out various strategies from peaceful dialogue, demonstrations, hostages, to arson. Fishermen resolved the resource conflicts by means of peace or violence. Resource conflicts at the level of brutality are influenced by livelihood problems and depend on the resolution process. If the conflict resolution process drags on, peaceful resolution does not succeed, conflict tends to be brutal (Kinseng, 2007).

Eco-sociological approach sees conflict as the result of clash of interests and the developed social-environmental positions and relationships that develop following social interactions. Conflict is a social relationship between social actors characterized by opposition and anger, whether expressed openly or not in order to achieve their own desires (Kinseng, 2013). Struggles in natural resource conflicts also involve emotions that make conflicts complex and damage stakeholder relations (Sultana, 2011). From a psychological point of view, conflict is a perception of differences in interests or the belief that the aspirations of the conflicting parties cannot be achieved simultaneously (Pruitt \& Rubin, 2004), the different objectives of the parties that are mutually bound (Littlejohn \& Domenici, 2007). The differences in perception are the main conditions for conflicts (Putnam, 2013).

Establishing communication among stakeholders to manage conflicts at a latent stage by identifying potential conflicts in the early stages prevent escalation (Kapelus et al. 2011). Open communication is often avoided by those who win the competition. Communication serves as a mechanism that ensures social equality in a group (Leibbrand 
\& Saaksvuori, 2012). The space for dialogue should be opened and free from the dominance of power so that open communication creates intersubjective communication in which the community and the power of interests reach consensus through non-violent arguments (Susan, 2009). Consensus is achieved by attaining mutual understanding (Kincaid \& Rogers, 1981).

In the conflict of fisheries resources in Bangladesh, communication played an important role in building consensus among opposing parties in various settings. Communication between stakeholders is the main key in the process of understanding each other, managing and resolving conflicts (Jahan et al. 2009). Communication is not the only method of conflict resolution, but the absence of communication between parties will increase conflict (Adejimola, 2009). Open communication among conflicting groups reduces the output of conflict and encourages disputants to work together to win the disputes (Leibbrand \& Saaksvuori, 2012) as well as leads to the reduction of destructive competition processes (Cason et al. 2012).

Interactive communication model is in accordance with the climate of a democratic society (Sumardjo 2006). Interaction of conflicting parties is directed towards a collaborative approach carried out by (1) participatory involvement of the parties, (2) interaction style which prioritizes dialogue and avoids the domination of one party, (3) clear rules of the game and mutual agreement, (4) method used is participatory and dialogical, (5) involving mediators from local leaders, both formal and non-formal, (6) avoiding involvement of leaders who have their own vested interests (Sumardjo et al. 2014). At the level of group communication, group communicators from the community are religious leaders / community leaders as opinion leaders. Opinion leader communication with the community plays an important role in preventing natural resource conflicts (Siagian et al. 2013) and open conflict resolution (Fitriyah, 2015).

The research aims to answer the problem concerning on how coastal utilization conflicts in the North Coast of Serang Regency is created? How is the communication among the conflicting parties in the relation of coastal resource utilization conflict? How is the effectiveness of communication and conflict resolution? How do the communication strategy for managing potential conflict and its escalation reach consensus based on convergence of interests? This research is expected to produce novelties namely analyzing natural resource conflicts from the perspective of development communication. The research focuses on communication practices in managing conflict in the coastal resources utilization, communication interaction of the conflicting parties, various communication efforts in conflict solutions and their effectiveness as well as producing communication strategies to manage conflict potential.

\section{RESEARCH METHOD}

The research approach used qualitative approach with a case study (Creswell, 2007). The research was conducted in July 2017 until July 2018. The sources of the primary data were collected by participant observation and in-depth interview to 16 informants involved in the conflict of coastal and marine resources utilization including fishermen, community leaders, managers of Lontar Fish Auction Market (TPI), seaweed farmers, activists from non-governmental organizations (NGOs), local governments and sea sand mining companies. Secondary data collection was done by using literature studies of previous research and documentation studies including government documents and the news from local and national newspaper. Data analysis was carried out using interactive models (Miles et al. 2014).

\section{RESULTS AND DISCUSSION}

\section{Conflict and Communication Typology}

The policy of utilization of the north coast in Serang Regency to become the location of sand mining has resulted in a structural conflict between the Government of Serang Regency, the Government of Banten Provin- 
ce, PT. Jetstar, as the sand mining company dealing with affected local communities. Sea sand mining activities that are administratively located in the waters of Lontar Village triggered the resistance from people living in northern coastal villages including Pontang, Tengkurak, Tanara, Lontar, Singarajan, Domas, Sujung and Susukan villages who mostly worked as fishermen. According to Sumardjo (2015), the typologies of north coast utilization conflict are demonstration, anarchism, social conflict of community layers which have reached the stage of human rights violations (Figure 1). Every party was not profitable in conflict because it affected material losses, mental and social damage.

Sea sand mining activities on the north coast of Serang Regency have been carried out since 1997 (New Order Era), but the conflict was manifested since 2003-2016 (Reformation Era). The conflict was open because the political system in Indonesia was more democratic so that it opened the space for coastal communities to express their opinions, attitudes and actions in the public boldly and openly. The majority of coastal communities working as fishermen conducted demonstration to fight for their interests in the regional government. In line with the research conducted by Kinseng (2017) that post-New Order era, fishermen fought for their interests openly. Soegijono (2015) argued that there would be an increase in the number of actors and masses involved in conflict which related to increasingly open social and political conditions.

When local government did not manage the conflict quickly or the conflict was protracted, public demonstrations tended to increase to be anarchism. Anarchic actions of coastal communities usually occurred when people demonstrates in emotional situations and in large numbers. Coastal communities that were emotional when getting provocative messages from other members, tended to be triggered to commit acts of human rights violations. According to Sultana (2011), the role of emotions in resource conflicts depends on the aspects of

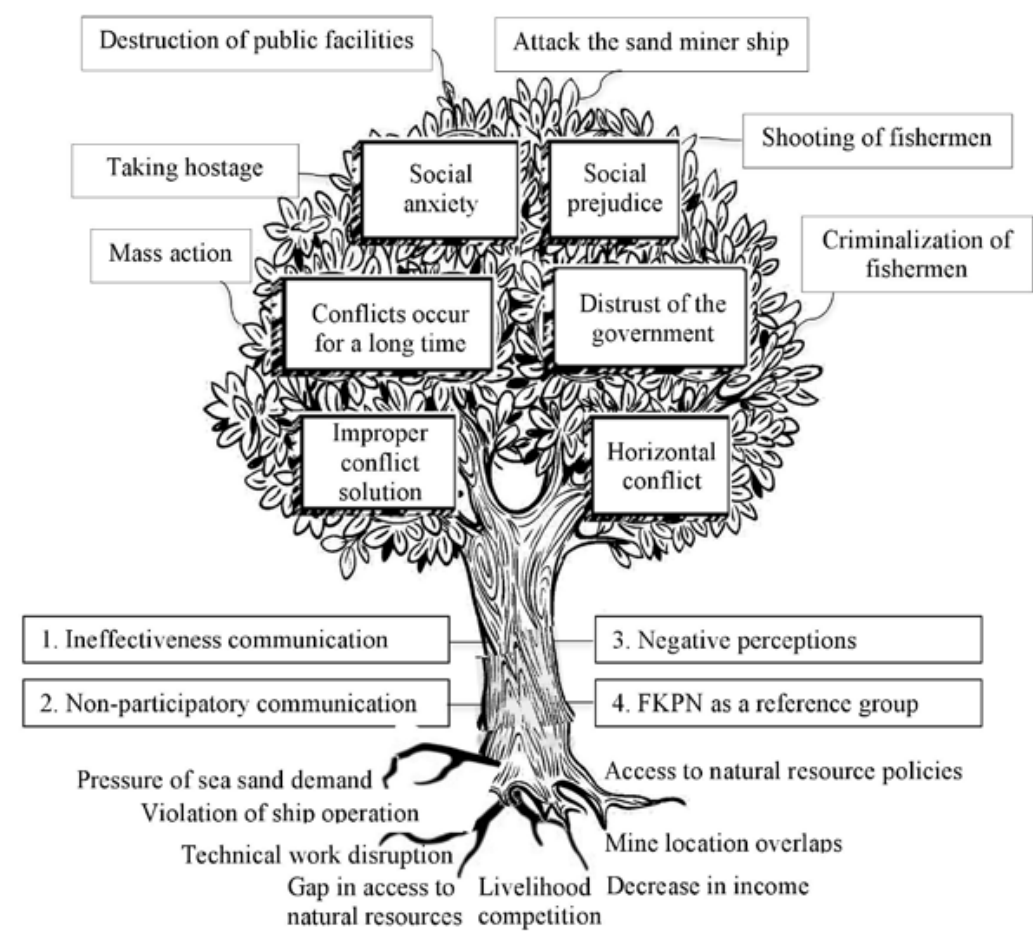

Figure 1. Tree of resource utilization conflict in the north coast of Serang Regency (modified from Sumardjo et al. 2014, researchers' processed data) 
location, community characteristics and natural resources.

The coastal communities who were actively involved were fishermen who depended their lives on the north coast. The condition of resources was full of the risks faced by fishermen, causing fishermen to have a strong, firm and open character (2015). Fishermen conflict concerning issues of access to fisheries resources tended to be brutal as revealed by Kinseng (2013; 2007). According to Sumardjo (2015), demonstration, as one of social movements, leads to anarchic and destructive actions caused by economic and political disparities triggered by dissatisfaction with the distribution of access, control and control over economic resources, resulting in marginalization and discrimination.

Based on the observable social symptoms, the root cause of the problem was (1) the gap in access of coastal communities with a majority of fishermen to fisheries resources including competition for fulfilling livelihoods, technical work disruptions and the decrease in income, (2) fishermen directly felt the impact of sand mining activities due to the access to natural resource policies whose location overlapped with fishing locations and weak local government supervision which made the company violated the production process (KLH, 2004), (3) market demand pressures made the company which has mining rights violated the use of fleet number and the widespread mine location points which resulted in the large scale of sea sand mining.

The main problems of the conflict between coastal communities with local governments and the company were caused by (1) communication ineffectiveness in managing potential conflicts to provide understanding of coastal communities about the impact of sand mining on the sustainability of fisheries resources, (2) communication which was not participatory because it did not involve fishermen groups, (3) negative perceptions of coastal communities about sea sand mining as a cause of decline in fishermen's income, reduced number of fish and abrasion in the north coast which damaged fish and seaweed cultivation land,
(4) communication role of 'Front Kebangkitan Petani dan Nelayan' (Farmers and Fishermen's Awakening Front) as a reference group for fishermen groups in the north coast.

Conflict is born from perception (Pruitt \& Rubin, 2004) and it marks interpersonal conflict (Putnam, 2013). The differences in perception trigger conflict because management of potential conflicts does not involve parties that represent the voice of fishermen (Annisa et al. 2009). Stakeholders in north coast resources are divided into two groups, namely the authorities, the regional government, and the company as the party that controls access and the users, the fishermen group as those who maintain the access. The differences in interest lead to the viewpoint of the authorities and the users of the north coast of Serang Regency who have different view in seeing the sources of the problems (Priyatna, 2013).

Whereas on the other hand, FKPN's interactive communication with the people of coastal villages face-to-face (primary) and through the fishermen's communication network (secondary) triggered fishermen group (quasi-group) to turn into interest group. The intensive communication conducted by FKPN, increased latent interests (perceptional) into manifest interests and triggered conflicts which were initially latent into manifest conflict. FKPN had been developed into "opinion leaders" who acted as a source of coastal people's action preferences in open conflict as required by Dahrendorf (1986).

FKPN has the power and role towards fishermen group because most of them are boat owners (juragan), capital owners (langgan) and fish collectors (bakul). According to Amiruddin's (2014) research, it is stated that traditional fishermen in Lontar Village have a dependency on life to langgan (customers) and bakul. This tended to apply in the villages along the north coast of Serang Regency. In the case of coastal community conflict, the power relations of Lontar's fishermen to Langgan and Bakul played an important role in the involvement of Lontar's fishermen in open conflict. FKPN, as a pla- 
ce to struggle, had the legitimacy of coastal communities and the structure of power relations to fishermen group in the north coast.

\section{Communication and Natural Resource Conflict}

The conflict of the north coast utilization regime is a destructive conflict which damages the social and physical order because the conflict relations that are built are competitive with the output of conflict between one party who wins and the other who loses. Destructive conflicts are influenced by the individual characteristics of the conflicting parties during the interaction process. Destructive conflicts are created when the parties involved in the process of conflict have negative attitudes and feelings that are mutually hostile to each other (DeFleur et al. 2014). The conflict between Serang Regency Government and PT. Jetstar with coastal communities is an inter-group conflict that has occurred since 2003-2016. Conflict between groups is often complex and diffi- cult to solve because it involves many people and involves a long history of previous conflicts (Tubbs, 2013). The conflict map of coastal resource utilization during the period of conflict consists of coastal community groups, local governments, IUP owning companies, police, TNI (Indonesian National Army), and community organizations.

The pattern of social relations between the parties involved in the conflict is cooperative relations and conflict relations. The pattern of relations among conflicting parties in the coastal resources utilization in Serang Regency is divided into two groups, namely the "pro" sand mining group and the "contra" sand mining group. The party which is pro sand mining is the local government from the village level and to higher level. PT. Jetstar was collaborating with Baladika Cooperative and Tirta Niaga Pantura Cooperative to maintain public conduciveness and management of Corporate Social Responsibility (CSR) compensation funds to the affected communities, community leaders and "Jawara". Community

Table 1. The mapping of relations of parties involved in north coast resources utilization conflict in Serang Regency (source: data processed by researchers).

\begin{tabular}{|c|c|c|c|c|c|c|c|c|c|c|c|c|c|c|c|}
\hline No & Conflict party & 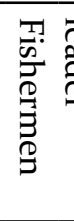 & 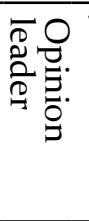 & & 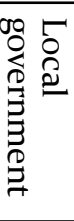 & 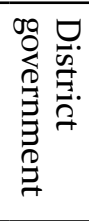 & 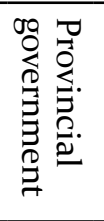 & 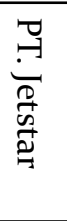 & 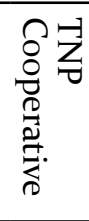 & 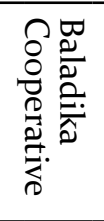 & $\frac{0}{\stackrel{0}{0}}$ & Z & $\begin{array}{l}\text { T: } \\
\text { Z }\end{array}$ & 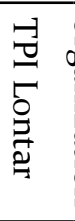 & 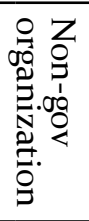 \\
\hline 1 & Fishermen & & - & - & - & - & - & - & - & - & - & + & + & + & + \\
\hline 2 & Opinion leader & - & & + & + & + & + & + & + & + & + & + & - & - & - \\
\hline 3 & Jawara & - & + & & + & + & + & + & + & + & + & + & - & - & - \\
\hline 4 & $\begin{array}{l}\text { Local government } \\
\text { (village level) }\end{array}$ & - & + & + & & + & + & + & + & + & + & + & - & - & - \\
\hline 5 & District government & - & + & + & + & & + & + & + & + & + & + & - & - & \\
\hline 6 & $\begin{array}{l}\text { Provincial govern- } \\
\text { ment }\end{array}$ & - & + & + & + & + & & + & + & + & + & + & - & - & - \\
\hline 7 & PT. Jetstar & - & + & + & + & + & + & & + & + & + & + & - & - & - \\
\hline 8 & TNP Cooperative & - & + & + & + & + & + & + & & + & + & + & - & - & - \\
\hline 9 & Baladika Cooperative & - & + & + & + & + & + & + & + & & + & + & - & - & - \\
\hline 10 & Police & - & + & + & + & + & + & + & + & + & & + & - & - & - \\
\hline 11 & TNI & + & + & + & + & + & + & + & + & + & + & & + & + & + \\
\hline 12 & FKPN & + & - & - & - & - & - & - & - & - & - & - & & + & + \\
\hline 13 & TPI Lontar & + & - & - & - & - & - & - & - & - & - & - & + & & + \\
\hline 14 & $\begin{array}{l}\text { Non-government } \\
\text { organization }\end{array}$ & + & - & - & - & - & - & - & - & - & - & - & + & + & \\
\hline
\end{tabular}


leaders and "Jawara" tended to work with the government and the company. "Jawara" in Banten Province is the dominant group in rural communities who has expertise in martial arts which acts as a tool of government power to subjugate other community groups (Kurniawan, 2012), the role of "Jawara" is closely related to regional government policies (Muslim et al. 2015).

The contra sand mining community groups are coastal communities who work as fishermen including fish and seaweed farmers, groups of community organizations engaged in fishermen and environmental advocacy including administrators of Lontar Fish Auction Market (TPI), FKPN, Indonesian Forum for the Environment (WALHI), The People's Coalition for Fisheries Justice (KIARA) and the Jakarta Legal Aid Institute (LBH). The parties who are contra to the mining have a conflict with the police as a security and public order party. It is different from the TNI which is collaborative with all groups involved in the conflict.

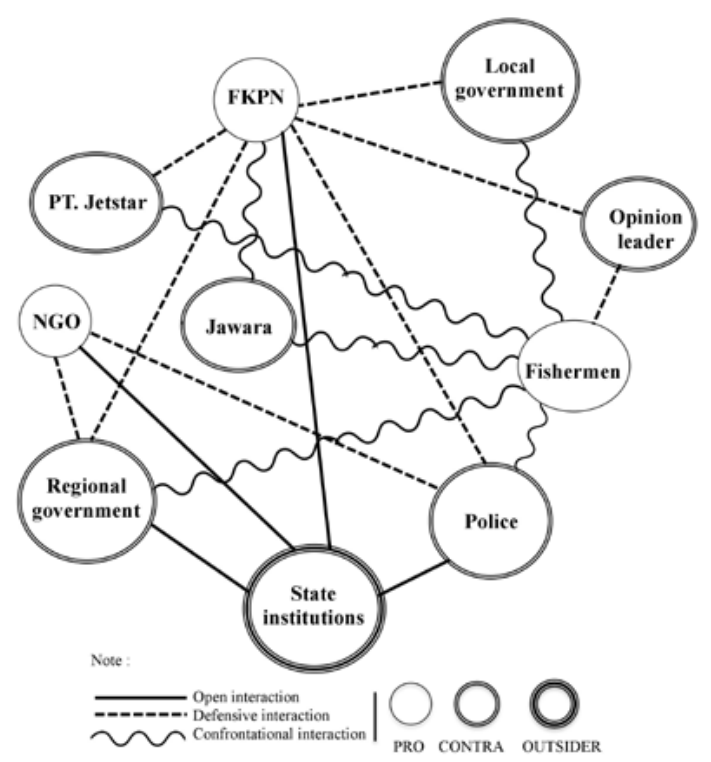

Figure 2. The communication of parties involved in north coast resources utilization conflict in Serang Regency (source : researchers' processed data).

The Government of Serang Regency and PT. Jetstar as the owner of legal authority tended to avoid open communication with coastal communities, they were said by Leibbrand and Saaksvuori (2012) as a group that will win the contest. When FKPN initiated open communication but it did not get any response from the local government, the communication pattern turned into defensive. Defensive communication is the process of communication between conflicting parties who experience a tension relationship which tends to attack opponents of communication and confrontation (Kaye 1998). The communication of someone, which is defensive, communicates to fight for his/her rights, always feels right, wants to win alone and does not see mistakes in himself/herself (Littlejohn \& Domenici 2001).

FKPN, along with coastal communities, the majority of which are fishermen groups, have repeatedly carried out defensive dialogues with the Government of Serang Regency and it produced an agreement regarding the termination of sea sand mining activities. When the local government or the company took several actions that violated the agreement from the results of the previous dialogue, fishermen tended to close communication channels and interacted confrontationally. Confrontational communication is the expression of anger in the form of words, attitudes and open actions which cause physical, mental and social damage done by one party to the other. Fishermen closed communication channels because fishermen no longer had trust in local government and the company. The closed communication for any dialogue increased the escalation (Adejimola, 2009), and caused violence (Engel \& Korf 2005; Susan 2009).

When the communication channel with the Serang District Government was closed, FKPN conducted open communication with various state institutions that have the authority / authority over the Serang District Government to fight for complaints from coastal communities. FKPN's open communication with parties outside the conflict (external) led to the reduction of destructive competition processes, not just communication between conflict parties (Cason et al. 2012). It enabled to generate 
conflict resolution based on external interventions or other state institutions (Kriesberg, 2003).

\section{Communication Effectiveness and Conflict Resolution}

Local governments and the company have made various communication efforts with coastal communities for conflict resolution. The communication strategies of the regional government and companies are carried out when the conflict problem is manifested (manifest). Governments and companies tended to take coercive actions to coastal communities to resolve conflicts. Various local government and corporate communications with coastal communities tended to be less effective because the communication pattern was unidirectional, the purpose of communication was informative, the communication technique of the message delivery style was instructive, the position of government and companies was more dominant and communication participants did not represent fishermen groups. The less effective communication of conflict parties for conflict solutions does not facilitate consensus based on convergence of interests (table 3).

Conflict of coastal and marine resources utilization in Serang Regency based on the sequence of conflict events occurred in several rounds of periodic conflicts, namely in 2003-2004, 2011-2014, and in 2015-2016. The Government of Serang Regency had an active role in communicating in the resolution of the 2003-2004 conflict. The company had an active role in communicating with coastal communities in 2011-2014 after the employment contract required companies to resolve community conflicts together with the local government. The conflict moved to the Banten Provincial Government since 2015-2016 as an implication of Law No. 24 of 2014 relating mining affairs to the authority of the provincial government. Local government communications and companies with coastal communities produced solutions to conflicts (table 2).

The Government of Serang Regency, Lontar District and Village communicated with some of the coastal communities of Lontar to provide support for sand mining activities with compensation including: (1) construction of coastal breakwater dam, (2) coastal mangroves planting for abrasion control, and (3) reactivation of Lontar Fish Auction Market (TPI). The unidirectional pattern of local government communication did not facilitate the aspirations of coastal communities' interests. Communication participants who did not represent groups of fishermen as affected groups made less effective communication for conflict solutions. The provision of compensation from local governments that did not represent the aspirations of the interests of fishermen triggered a demonstration of the community of other coastal villages.

PT. Jetstar collaborated with Tirta Niaga Pantura Cooperative to maintain the security of sea sand mining operation. TNP Cooperative Manager involved "Jawara” group and police in carrying out coercive actions in the form of threats, intimidation and criminalization of fishermen for conflict resolution. The communication of TNP Cooperative, Jawara and police to coastal communities was carried out with coercive communication techniques, namely the delivery of messages in the form of orders, instructions and even bribery containing sanctions and threats (Effendy, 2008), forcing other people to obey those who are "in power" in the form of threats, punishment and physical action (Liliweri, 2011). The criminalization of Lontar fishermen triggered the Lontar community to "occupy" Serang police station and take TNP Director as their hostage. Coercive communication technique is not effective because it tends to trigger other coercive communication and conflict escalation.

PT. Jetstar collaborated with the Baladika Cooperative to conduct community security and control. Baladika Cooperative Manager openly communicated coercively to community leaders, fishermen group, coastal communities about the provision of compensation funds from PT. Jetstar which was managed by the CSR Team. The Baladika Cooperative carried out personal coercive 
Table 2. The results of communication between the central government, regional government, the company and coastal communities as a solution to the conflict and its implications

\begin{tabular}{ccc}
\hline $\begin{array}{c}\text { Source of con- } \\
\text { flict }\end{array}$ & Conflict solution & Implication \\
\hline
\end{tabular}

The gap in ac- The plantation of mangroves on the The communities of villages concessing natural coast, the establishment of breakwa- ducted demonstrated resources ter dam and the reactivation of Lontar Fish Auction Market (TPI)

The TNP Cooperative collaborated FKPN and the communities were with Jawara to threaten and intimi- increasingly massive in protestdate fishermen and report the perpe- ing and fishermen were increastrators of the attack on the fleet to the ingly anarchist in attacking the police operating fleets

The provision of CSR funds man- Horizontal conflict between the aged by Baladika Cooperative which Lontar communities between involved communities and FKPN net- fishermen and non-fishermen work in Lontar

The compensation of CSR funds in It triggered the previously closed the amount of Rp. $1.500 / \mathrm{m}_{3}$ which conflict to be an open conflict was collectively managed with communities was rejected by fishermen

The Pressure on The socialization of the Jakarta Bay Lontar communities reported market demand reclamation moratorium was fol- PT. Jetstar which was still operatfor reclamation lowed up by the Governor of Banten ing to the Indonesian Parliament of PIK - Jakarta with a moratorium of sea sand min- (DPD), Banten Provincial DPRD, Bay ing KKP and Ombudsman

Access of natu- Banten Provincial Government inter- The Government of Serang Reral resource pol- vention and Minister of Environment gency did not extend the proicies Republic of Indonesia to pause and duction operation permit of PT. conduct an environmental evaluation Jetstar involving the communities

communication to conflicting actors from fishermen group, fisherwomen and FKPN mass network to no longer be involved in conflicts and force them to join the CSR Team of PT Jetstar. Open and personal coercive communication technique successfully managed to reduce conflict but it did not build consensus for resolving the conflict. The provision of CSR funds managed by Baladika Cooperative and coastal communities caused horizontal conflict between Lontar communities who are fishermen and nonfishermen.

PT. Jetstar and Banten Provincial Government communicated with the local leaders (RT and RW), and representatives of fishermen (Lontar Fish Auction Mar- ket) about the cooperation with the Lontar community in sand mining activities with compensation of CSR funds of Rp. 1,500 / $\mathrm{m} 3$ which was managed collectively with the community. The company and regional government were more dominant as the participants of communication and their style of message delivery was instructive, namely the delivery of messages that positions the participants of communication as "superiorinferior". The government and company did not care about the aspirations of fishermen to make an agreement to control the postoperation environmental impacts. As the result, the communication between conflicting parties was less effective to satisfy both parties. Fishermen returned to protest sand 
mining operation.

The intervention of state institutions as the third party played a role in resolving the conflict: (1) The Banten Provincial Government conducted instructive communication through Banten Governor's letter Number 541/35/313Bpdl/VI/2004 to temporarily stop sand mining from not fulfilling the provisions of Constitution No. 23 of 1997 and Presidential Decree No. 33 of 2002 concerning on AMDAL and marine spatial planning, (2) Ministry of Environment (KLH) formally communicated through Minister of Environment's letter Number: B-259/ MENLH/05/2004 to temporarily stop sand mining because it was disturbing the community and fulfilling the requirements regarding evaluation study of PT. Jetstar Phase I, (3) The central government conducted socialization concerning on the termination of the Jakarta Bay reclamation moratorium based on the Letter of the Coordinating Minister for Maritime Affairs Number: 27.1/ Menko/Maritime/IV/2016 and it impacted on the Banten Governor's decision on moratorium of sea sand mining.

\section{Communication Strategy for Manag- ing Conflict Potential}

The conflict of resources utilization needs to be managed constructively through the process of communication between the parties who are involved in the conflict. Managing conflict potential is in order to minimize the impact of conflict. The communication of stakeholders in the early stages of conflict/ conflict potential plays an important role in preventing conflict escalation (Kapelus et al. 2011). Communication strategy for managing conflict potential prevents open ( $m a-$ nifest) conflict and the escalations are possible: (1) before the parties do not trust each other (Kriesberg, 2003), (2) before the affected groups as quasi-groups form conflict groups/ formed manifest interests (Dahrendorf, 1986), (3) before the communication between members of the conflict group builds identity and collectivity (Kriesberg, 2003), and increases aggressiveness to other groups (Leibbrandt \& Saaksvuori, 2012), (4) before the intensity of conflict increases with increasing differences, mobilizing strength and interests (Engel \& Korf, 2005).

The communication strategy of regional governments and the company with coastal communities are managed in a planned manner (table 3). The communication between conflicting parties is carried out in the process of providing community support to the company as a condition of environmental permit to obtain IUP and the setting of AMDAL as regulated in the Environmental Management and Protection Act (PPLH) Number 32 of 2009. Local government must understand the conflict potential of coastal resources utilization policies and the importance of managing conflict before the escalation of conflict is emerged and difficult to stop. Managing conflict is entirely dependent on the Regional Government as the party that has the authority to issue IUP. Coercive approach tends to invite similar actions, expands conflict and encourages destructive characteristics (Engel \& Korf, 2005).

Decentralization demands an approach to regional governance that is interactive with regional needs and local aspirations. The interactive communication model is dialogic, humane and in accordance with the community climate with democratic character (Sumardjo, 2006). The interaction of conflicting parties is directed to problemsolving approach and is satisfying both parties, "win-win solution". Some elements that must be considered are (1) encouraging the involvement of the parties in a participatory manner, (2) the style of interaction puts forward a dialogical approach and avoids the dominance of one party, (3) clear rules of the game and mutual agreement, (4) the methods used are participatory and dialogical, (5) facilitating the existence of mediators from local leaders, both formal and non-formal, (6) avoiding the involvement of leaders who have their own vested interests (Sumardjo et al. 2014).

The communication practice between local government and the company with coastal communities must involve all groups of people who are directly affected, especially those who were rejecting sea sand 
Table 3. The comparison of occurred and suggested communication practice in managing north coast utilization conflict potential in Serang Regency

\begin{tabular}{|c|c|c|c|}
\hline \multirow[b]{2}{*}{ No } & \multirow[b]{2}{*}{ Issue } & \multicolumn{2}{|c|}{ Communication strategy for managing conflict potential } \\
\hline & & $\begin{array}{c}\text { Occurred communication } \\
\text { practice }\end{array}$ & $\begin{array}{c}\text { Suggested communica- } \\
\text { tion practice }\end{array}$ \\
\hline 1 & Conflict stage & $\begin{array}{l}\text { When the conflict is in mani- } \\
\text { fest form }\end{array}$ & $\begin{array}{l}\text { When the conflict is la- } \\
\text { tent or conflict potential }\end{array}$ \\
\hline 2 & Conflict management & Coercive & Collaborative \\
\hline 3 & Communication pattern & Linear communication & Interactive \\
\hline 4 & $\begin{array}{l}\text { The purpose of commu- } \\
\text { nication }\end{array}$ & Informative & Building consensus \\
\hline 5 & $\begin{array}{l}\text { The style of message de- } \\
\text { livery }\end{array}$ & Instructive & Persuasive \\
\hline 6 & $\begin{array}{l}\text { Communication partici- } \\
\text { pant }\end{array}$ & $\begin{array}{l}\text { Not representing the groups in- } \\
\text { volved in the conflict }\end{array}$ & Involving all parties \\
\hline 7 & $\begin{array}{l}\text { The structure of com- } \\
\text { munication participant }\end{array}$ & $\begin{array}{l}\text { Local governments and the } \\
\text { company are more dominant }\end{array}$ & $\begin{array}{l}\text { Equality of communica- } \\
\text { tion and egalitarian }\end{array}$ \\
\hline
\end{tabular}

mining such as north coast fishermen, the administrator of Lontar Fish Auction Market (TPI), fish/seaweed farmers, community organization leaders and their networks that were actively involved in the conflict beforehand. Inter-group communication tends to be represented by coastal community leaders. Therefore, religious leaders and community leaders both structural and cultural must be involved. The involvement of communication from coastal community leaders aims to prevent natural resource conflicts among the community in the early stage (Siagian et al. 2013) or when it is open (Fitriyah, 2015).

The communication flow of the local government, the company and coastal communities adopted Bolton collaborative approach (in Kaye 1994), which was managed in stages, namely: (1) conducting dialogue about the negative perceptions of coastal communities, particularly fishermen groups regarding the location of mining, shipping technical difficulties, and operational violations, (2 ) conveying persuasive messages to find a solution that enables it to minimize the impact of sand mining on fishermen's welfare and empowerment of coastal communities, (3) determining solutions related to mining locations, monitoring production and security as well as targeted compensation and CSR implementation that meets the needs of both parties (4) making agreement on the implementation and supervision of sand mining production and the implementation of community-based CSR to manage conflict (5) determining action plans based on agreements (6) taking action based on the agreement.

The communication between local governments and the company with coastal communities was managed effectively with communication structures that facilitated the equality of communication participants to encourage openness and empathy (Devito, 2013), because the communication between parties involved in the conflict tended to dominate and control the other parties. (Littlejohn \& Domenici, 2007). Every communication participants from the local government, company and coastal communities interacted openly, free from domination and discursive so that each communication participant reached consensus through non-violent argumentation (Susan, 2009). Conflict parties' consensus was achieved by communication participants by interacting, creating and sharing information with each other to achieve mutual understanding (Kincaid \& Rogers, 1981). 


\section{CONCLUSION}

The gap in the coastal resources utilization becomes the trigger of the conflict between local government, the company and coastal communities. The communication of the local government and sand mining company to coastal communities which was less effective is unable to establish an understanding of the impact of sand mining on the sustainability of fisheries resources. FKPN's communication encouraged the transformation of fishermen groups into conflict groups that are fighting for their interests. Coastal communities fought for their interests in various forms such as demonstrations, anarchism, social conflicts between layers and human rights violations. The emotion of coastal communities, exposure to messages and the number of mass demonstrations, sometimes, play a role in conflict escalation.

Conflicting parties are divided into two sides, "pro" sand mining and "contra" sand mining parties. The communication of conflicting parties occurred openly, defensively and in confrontational way. FKPN interacted defensively with the contra sand mining group, covering regional governments from the village to the provincial level, sand mining company, community leaders and the police. While, FKPN's communication with various state institutions that have power over the Government of Serang Regency is open to each other. Fishermen communicated in a confrontational manner with the local government from the village to the provincial level, the company, and the police, but communicated defensively with community leaders. Jawara communicated confrontationally with FKPN and fishermen. NGOs only communicated with the regional government and the police defensively.

Communication practice between local government and the company for conflict resolution is less effective because it does not involve all coastal communities involved in the conflict. Local government and the company managed conflicts coercively through the practice of coercive communication of "Jawara" and the administrators of TNP Cooperative. The coercive communication practices of government and the company tends to produce feedback on coercive actions. Whereas the coercive communication of the Baladika Cooperative to coastal communities, especially conflicting actors, dampen the temporary conflict, but it does not produce consensus for a solution to the conflict. Intervention of communication from external parties including Banten Provincial Government, the Ministry of Environment and the Maritime Coordinating Ministry as third parties, play a role in resolving the conflict.

This research suggests to make an effective communication channel between local government and the company with coastal communities to manage conflict potential and its escalation by reaching consensus based on convergence of interests. The flow of communication between local government, the company and communities is managed in stages to bring collective needs, interests and agreements as a conflict solution from the sources of conflict. The communication practices of conflicting parties are carried out during the latent conflict/conflict potential collaboratively based on interactive communication patterns, communication which aims to build consensus, persuasive communication message styles, communication participants representing all coastal communities with equal and egalitarian communication participant structures.

\section{REFERENCES}

Adejimola, A. S. (2009). Language and communication in conflict resolution. Journal of Law and Conflict Resolution, 1(1), pp. oo1-0o9.

Amiruddin, S. (2014) Jaringan Sosial Pemasaran Pada Komunitas Nelayan Tradisional Banten. Komunitas: International Journal of Indonesian Society and Culture, 6(1), pp. 106-115 DOI: 10.15294/komunitas.v6i1.2949.

Annisa, L., Satria, A. and Kinseng, R.A., (2009). Konflik Nelayan Di Jawa Timur: Studi Kasus Perubahan Struktur Agraria dan Diferensiasi Kesejahteraan Komunitas Pekebun di Lebak, Banten. Sodality: Jurnal Sosiologi Pedesaan, 3(1). pp. 113-124.

Cason, T.N., Sheremeta, R.M. and Zhang, J., (2012). Communication and efficiency in competitive 
coordination games. Games and Economic Behavior, 76(1), pp.26-43.

Creswell, J.W. (2007). Qualitative Inquiry\& Research Design: Choosing Among Five Approaches. Second Edition. California: Sage Publications.

Dahrendorf R. (1986). Konflik dan Konflik dalam Masyarakat Industri : Sebuah Analisa Kritik. Jakarta (ID): CV Rajawali.

DeFleur, M.H., Kearney, P., Plax, T.G, DeFleur, M.L., (2014). Fundamentals of Human Communication : Social Science in Everyday Life, Fourth Edition. New York (NY) : McGraw-Hill Companies, Inc.

DeVito, J.A. (2013). The Interpersonal Communication Book, Thirteenth Edition. New York (NY) : Pearson Education Inc.

Effendy, O.U. (20o8). Dinamika Komunikasi, Cetakan ketujuh. Bandung (ID): PT. Remaja Rosdakarya

Engel, A., Korf, B. (2005). Negotiation and mediation techniques for natural resource management. Food and Agriculture Organization of the United Nations (FAO), Rome.

Fitriyah, N. (2012). Strategi Komunikasi Dalam Upaya Penanganan Konflik Pembangunan Industrial : Studi Kasus Konflik Masyarakat Padarincang Terhadap Pembangunan PT. Aqua Danone, Jurnal Riset Komunikasi, 3(6), pp. 309-320.

Huma. (2013). Outlook Konflik Sumberdaya Alam dan Agraria 2012, Avalaible at: https://huma. or.id/home/pusat-database-dan-informasi/ outlook-konflik-sumberdaya-alam-dan-agraria-2012-3.html.

Kaye M. (1998). Communication Management. Sydney : Prentice Hall Australia.

Kapelus P, Richards E, Sherwin H. 2011. Conflict-sensitive impact assessment. In: Vanclay F, Esteves AM, editors. New directions in social impact assessment. Cheltenham, UK: Edward Elgar Publishing.

KPA. (2015). Reforma Agraria dan Penyelesaian Konflik Agraria Disandera Birokrasi, Avalaible at: http://kpa.or.id/publikasi/baca/Laporan/31/ Catahu_2015:_Reforma_Agraria_dan_Penyelesaian_Konflik_Agraria_Disandera_Birokrasi.

Kinseng, R. A. (2007). Konflik-konflik sumberdaya alam di kalangan nelayan di Indonesia. SODALITY, 1(1), pp. 87-104. Doi: 10.22500/sodality.vii1. 5936

Kinseng, R. A. (2013). Identifikasi Potensi, Analisis dan Resolusi Konflik, in Victor PH Nikijuluw, Luky Adrianto, dan Nia Januarini (editor). Coral Governance. Bogor (ID): IPB Press

Kinseng, R. A. (2017). Decentralisation and the Living Conditions and struggle of Fishers : A Study in West Java and East Kalimantan. Journal of Sustainable Development, 10(1), pp. 71-82.

KLH. (2004). Laporan Verifikasi Kasus Penambangan Pasir Laut oleh PT. Jetstar di Desa Lontar, Kecamatan Tirtayasa, Kabupaten Serang, Banten.

Koran Radar Banten. (2004). Djoko Desak Bunyamin Stop Pengerukan Pasir, Koran Radar Banten,
Juni 25.

Kriesberg, L. (2003). Constructive conflict: From escalation to resolution $\left(2^{\text {nd }}\right)$. Lanham, MD: Rowman and Littlefield Publisher, Inc.

Kurniawan, B. (2012). Kearifan Lokal di Tengah Arus Pembangunan. WELFARE, Jurnal Ilmu Kesejahteraan Sosial, 1(2), pp. 225-238.

Leibbrandt A, Saaksvuori L. (2012). Communication in intergroup conflicts. European Economic Review, 56(1), pp. 1136-1147. doi:10.1016/j.euroecorev.2012.05.003.

Liliweri, Alo. (2011). Komunikasi Serba Ada Serba Makna. Jakarta (ID): Kencana.

Littlejohn, S.W, Domenici, K. (2001). Engaging communication in conflict: systemic practice. London : Sage Publication Inc

Littlejohn, S.W, Domenici, K. (2007). Communication, conflict, and the management of difference. Illnois : Waveland Press, Inc.

Menteri Negara Lingkungan Hidup Republik Indonesia. (2004). Surat Nomor B-2529/MENLH/o5/2004: Rekomendasi Tindak Lanjut Kasus Penambangan Pasir Lepas Pantai Oleh PT. Jetstar. Jakarta.

Murshed-e-Jahan, K., Salayo, N.D. and Kanagaratnam, U. (2009). Managing fisheries conflicts through communication planning: Experience from inland fisheries of Bangladesh. Fisheries Research, 99(2), pp.112-122.

Muslim A, Kolopaking LM, Dharmawan AH, Soetarto E. (2015). Dinamika Peran Sosial Politik Ulama dan Jawara di Pandeglang Banten. MIMBAR, 31(2), pp. 461-474.

Miles MB, Huberman M, Saldana J. (2014). Qualitative Data Analysis: a Methods Sourcebook. Third edition. California (US): Sage Publications.

Nurzal ER. (2004). Upaya Penanganan Pasir Laut Dari Sisi Kebijakan. Jurnal Teknologi Lingkungan $P_{3} T L-B P P T$, 5(3), pp. 212-220. DOI: http:// dx.doi.org/10.29122/jtl.v5i3.318.

Putnam, L.L. (2013). Definitions and Approaches to Conflict, in Oetzel JG, Ting-Toomey S, editors. The SAGE Handbook of Conflict Communication : Integrating Theory, Research, and Practice, Second Edition. London (UK): SAGE Publication, Inc.

Priyatna, F.N., Kinseng, R.A., Satria, A. 2013. Akses dan Strategi Aktor-aktor Dalam Pemanfaatan Sumber Daya Waduk Djuanda. Jurnal Sosek $K P, 8(1$, pp. 1-9.

Pruitt, D.G., Rubin, J.Z. 2004. Teori Konflik Sosial. Yogyakarta (ID) : Pustaka Pelajar.

Riyanto, S., Saleh, A. and Firmansyah, A., 2015. Tipologi Konflik Berbasis Sumber Daya Pangan di Wilayah Perkebunan Sawit. Jurnal Ilmu Pertanian Indonesia, 19(3), pp.189-196.

Rogers, E.M., Kincaid, D.L. 1981. Communication Network : Toward a New Paradigm for Research. New York (NY): The Free Press.

Satria, A. 2009. Ekologi Politik Nelayan. Yogyakarta (ID) : LkiS 
Satria, A. (2015). Pengantar Sosiologi Masyarakat Pesisir. Jakarta (ID): Diterbitkan atas kerjasama antara Fakultas Ekologi Manusia IPB dengan Yayasan Pustaka Obor Indonesia.

Siagianm H.F., Abdullah, M.Y., Mustaffa, N.B., Ahmad, F. (2013). K' Pola Penglibatan Dan Impak Komunikasi Para Ulama Mencegah Konflik Dalam Masyarakat. Jurnal Komunikasi KARE$B A, 2(1)$, pp. 41-54.

Sjaifuddin. (2007). Pengelolaan lingkungan wilayah pesisir dan laut teluk banten berkelanjutan. $\mathrm{PhD}$ Thesis, Sekolah Pascasarjana IPB.

Soegijono, S.P. (2015). Papalele : Dangerous Encounter and Transaction in Conflict. Komunitas: International of Indonesian Society and Culture, 7(2), pp. 297-306. DOI: 10.15294/komunitas. v7i2.4520.

Sultana, F. (2011). Suffering for water, suffering from water: Emotional geographies of resource ac- cess, control and conflict. Geoforum, 42(1), pp. 163-172. doi:10.1016/j.geoforum.2010.12.002.

Sumardjo. (2006). Komunikasi dalam Perspektif Ekologi Manusia. in : Adiwibowo S, editor. Ekologi Manusia. Bogor (ID): FEMA IPB.

Sumardjo. (2015). Pemberdayaan: Alternatif perluasan strategi deradikalisasi. Seminar Deradikalisasi, IPB Convention Centre Bogor, 13 Oktober 2015.

Susan, N. (2009). Sosiologi Konflik dan Isu-Isu Konflik Kontemporer. Jakarta (ID): Kencana Prenada Media Group.

Tubbs, S. (2013). Human Communication : Principles and Contexts, Thirteenth Editions. New York (NY): The McGraw-Hill Companies, Inc.

Turner, J. H. (1998). The Structure of Sociological Theory (Fifth Ed), Wadsworth Publishing Company. Belmont, California. 